\title{
SEKOLAH ISLAM TERPADU \\ DALAM SISTEM PENDIDIKAN NASIONAL
}

\section{Integrated Islamic Schools In The National Education System}

\author{
Suyatno \\ Prodi PGSD Universitas Ahmad Dahlan Yogyakarta \\ JL. Ki Ageng Pemanahan (UAD Kampus 5) No. 19, Sorosutan Yogyakarta \\ Email: Broery_jis@yahoo.co.id
}

Naskah diterima tanggal 3 Maret 2015. Naskah direvisi tanggal 9 April 2015. Naskah disetujui tanggal 22 Mei 2015

\begin{abstract}
Abstrak
Sekolah Islam Terpadu muncul sebagai respon atas ketidakpuasan para aktivis gerakan Islam terhadap sistem pendidikan nasional di Indonesia. Sistem pendidikan nasional dianggap melanggengkan dualisme dalam pengelolaan pendidikan antara pendidikan agama dan umum. Oleh karena itu, dibutuhkan sebuah model lembaga pendidikan alternatif yang mampu menghapus adanya praktek pendidikan yang dikotomis. Dalam perkembangannya, terjadi paradoks mengenai perkembangan Sekolah Islam Terpadu ketika mereka justru harus menjadi bagian dari sistem pendidikan nasional. Penelitian ini bertujuan untuk menjawab pertanyaan bagaimanakah posisi Sekolah Islam Terpadu dalam peta sistem pendidikan nasional Indonesia? Penelitian ini merupakan penelitian kualitatif dengan model studi kasus. Metode pengumpulan data dilakukan dengan observasi terlibat, wawancara mendalam, dan dokumentasi. Analisis data dilakukan dengan analisis induktif-kualitatif. Hasil penelitian menunjukkan bahwa Sekolah Islam Terpadu merupakan bagian integral dari sistem pendidikan nasional. Indikasinya adalah adopsi kurikulum dari kementerian pendidikan dan kebudayaan, penyesuaian sistem ujian, dan program sertifikasi oleh guru-guru Sekolah Islam Terpadu. Kesediaan mereka untuk menjadi bagian dari sistem pendidikan nasional merupakan salah satu upaya para aktivis gerakan Islam untuk melakukan islamisasi lembaga pendidikan formal di Indonesia.
\end{abstract}

Kata kunci: sekolah Islam terpadu, islamisasi, sistem pendidikan nasional.

\begin{abstract}
Integrated Islamic schools emerged as a response to dissatisfaction of Islamic movement activists against the national education system in Indonesia. National education system is considered to perpetuate the dualism in the education management between religion and public education. Therefore, a model of alternative education institution is badly needed which is capable of eliminating the dichotomous education practices. During its development, paradox regarding to the development of integrated Islamic school occurred when those actually have to be the part of the national education system. This study aims to answer the question of 'how is the position of integrated Islamic schools in the National Education map? This study is a qualitative case study model. The techniques of data collection were participant observation, in-depth interviews, and documentation. The data were analyzed by using inductive-qualitative analysis. The results showed that the integrated Islamic schools are the integral part of the national education system. The indications are the adoption of the curriculum of the ministry of education and culture, the adjustment of the examination system, and the certification programs obtained by teachers of integrated Islamic school. Their willingness to be part of the national education system is one of the attempts of the Islamic movement activists to carry out Islamization of the formal education institutions in Indonesia.
\end{abstract}

Keywords: integrated Islamic schools, islamization, national education system 


\section{PENDAHULUAN}

$\mathrm{S}$ ekolah Islam Terpadu merupakan pendatang baru dalam lanskap pengembangan model lembaga pendidikan di Indonesia. Meskipun baru berdiri pertama kali pada akhir abad ke-20 (Kadir, 2011), sekolah ini telah berkembang ke seluruh wilayah Indonesia. Lembaga pendidikan yang bermula dari Bimbingan Belajar Nurul Fikri ini, kini telah berkembang menjadi sebuah model lembaga pendidikan prestisius dari tingkat TK hingga SMA (Usamah Hisyam, 2011). Dalam waktu yang relatif singkat, jumlah sekolah Islam terpadu telah mencapai 10.000 sekolah di seluruh wilayah Indonesia (Suyatno, 2013a).

Kemunculan sekolah ini dilatarbelakangi oleh adanya ketidakpuasan sebagian besar aktor gerakan Islam di Indonesia terhadap perkembangan sistem pendidikan nasional (Suyatno, 2013b). Adanya dikotomi ilmu antara ilmu agama dan umum di sekolah telah menyebabkan lembaga pendidikan di Indonesia tidak mampu menciptakan lulusan yang berkepribadian utuh. Dikotomi ilmu akhirnya melembaga dalam bentuk dualisme sistem pendidikan nasional (Azra, 1998). Di satu sisi, ada sekolah-sekolah agama yang berada di bawah Kementerian Agama, mulai dari RA, MI, MTs, MA, hingga Perguruan Tinggi Agama Islam (PTAI). Di sisi lain, ada sekolah-sekolah umum yang berada di bawah Kementerian Pendidikan dan Kebudayaan mulai dari TK, SD, SMP, SMA, hingga Perguruan Tinggi Umum (PTU) (Sutrisno, 2011).

Dua model lembaga pendidikan ini diangggap oleh para pendiri Sekolah Islam Terpadu tidak mampu menjawab tantangan dan kebutuhan zaman. Lembaga pendidikan umum hanya membekali siswa tentang ilmu-ilmu umum yang jauh dari nilai-nilai tauhid. Hasilnya, meskipun para siswa memiliki kemampuan penguasaan sains dan teknologi, mereka tidak memiliki basic pendidikan moral yang kokoh sehingga dapat terjerumus ke dalam penyakit budaya modern, semisal; free seks, penggunaan narkoba, kenakalan remaja, dan lainlain. Sebaliknya, lembaga pendidikan Islam hanya membekali siswa tentang ilmu-ilmu agama ansich, sehingga mereka tidak mampu menguasai sains dan teknologi. Meskipun memiliki pondasi moral yang kuat, mereka tidak dapat eksis di tengah-tengah perkembangan zaman modern (Hasan, 2011).

Menurut para aktor gerakan Sekolah Islam Terpadu, kondisi pendidikan yang dualistik tersebut sudah tidak selayaknya dipertahankan. Kedua sistem tersebut harus ditinggalkan dan ditata ulang secara tuntas. Kedua sistem harus dipadukan secara integral. Sistem yang ditimbulkannya harus diisi dengan semangat Islam dan, meminjam istilah al-Faruqy, berfungsi sebagai sebuah bagian yang integral dari program ideologisnya (Al-Faruqy, 1984). Problem klasik tentang dikotomi maupun dualisme ilmu agama dan ilmu umum harus segera dicarikan solusinya baik pada tingkatan filosofis paradigmatik maupun sampai pada teknis departemental. Upaya pengembangan pendidikan harus menuju pada integritas antara ilmu agama dan ilmu umum sehingga tidak melahirkan jurang pemisah antara keduanya, sebab dalam pandangan Islam, ilmu pengetahuan adalah satu yaitu yang bersumber dari Allah swt (Sanaky, 2003: 100). Islam tidak pernah membedakan antara ilmu-ilmu agama dan ilmu umum atau tidak berpandangan adanya dikotomi dalam ilmu pengetahuan. Ilmu pengetahuan berasal dari satu sumber yaitu Allah swt.

Oleh karena itu, menurut para pendiri Sekolah Islam Terpadu, dibutuhkan sebuah lembaga pendidikan alternatif yang dapat menjembatani dualisme dalam sistem pendidikan nasional. Tidak hanya penguasaan sains dan teknologi semata, atau sebaliknya, hanya penguasaan ilmu agama ansich, siswa perlu dibekali sains dan teknologi dan ilmu agama secara utuh dengan pendekatan epistemologi yang integratif sehingga dapat menghasilkan siswa dengan kepribadian utuh pula.

Dalam perkembangannya, ada paradoks mengenai perkembangan Sekolah Islam Terpadu. Di satu sisi, latar belakang berdirinya lembaga ini adalah adanya ketidakpuasan terhadap sistem pendidikan nasional. Namun dalam perkembangannya, sekolah ini tetap menjadi bagian dari sistem pendidikan nasional. Ada beberapa indikasi yang menunjukkan bahwa Sekolah Islam Terpadu sebenarnya merupakan bagian dari sistem pendidikan nasional. Indikasi tampak dalam penggunaan nama "sekolah", penerimaan mereka secara total terhadap kurikulum nasional, sistem penilaian yang dilakukan, dan program sertifikasi guru (Suyatno, 2013). Oleh karena itu, perkembangan sekolah ini tampaknya telah bergeser dari tujuan awalnya.

Artikel ini berusaha menjawab pertanyaan bagaimanakah posisi Sekolah Islam Terpadu dalam peta sistem pendidikan nasional. Apakah para pendiri Sekolah Islam Terpadu tetap berpegang teguh pada niat awal bahwa sistem pendidikan nasional perlu dirombak karena tidak dapat 
menghasilkan siswa yang berkepribadian utuh. Ataukah telah terjadi pergeseran mengenai posisi Sekolah Islam Terpadu sehingga mereka menjadi bagian dari sistem pendidikan nasional. Jika mereka berpegang teguh pada pendapat pertama, mengapa mereka saat ini justru banyak menerima kebijakan dari pemerintah? Dan jika telah terjadi pergeseran dari tujuan semula, bagaimanakah dengan perjuangan ideologis para pendirinya?

\section{METODE PENELITIAN}

Penelitian ini merupakan penelitian kualitatif yang memiliki beberapa karakteristik yaitu; pertama, berlangsung dalam latar ilmiah (Nasution, 1998: 9-12); kedua, peneliti adalah instrumen atau alat pengumpul data yang utama; ketiga, analisis datanya dilakukan secara induktif (Moleong, 1989: 3). Menurut Yin, fokus penelitian lebih berusaha menjawab pertanyaan tentang "bagaimana" (Robert K. Yin, 1996: 18). Secara filosofis, sesuai dengan karakter data, teknik pengumpulan dan analisis penelitian ini mengacu pada pendekatan kualitative-naturalistic (Muhadjir, 2002: 17-18). Penelitian kualitatif lebih menekankan kepada makna (Sugiyono, 2006: 21-22).

Sumber data penelitian ini berasal dari data lapangan maupun data pustaka. Data lapangan diambil dari sepuluh Sekolah Islam Terpadu di wilayah Yogyakarta, dari tingkat TK hingga SMA. Penelitian lapangan dilakukan sepanjang pertengahan tahun 2013 hingga pertengahan tahun 2014. Data pustaka berupa artikel, makalah, dan buku-buku baik yang ditulis maupun yang diseminarkan oleh para pendiri Sekolah Islam Terpadu di berbagai forum ilmiah.

Teknik pengumpulan data yang digunakan meliputi; (1) observasi terlibat, (2) wawancara mendalam, dan (3) dokumentasi. Untuk menjamin akurasi data yang diperoleh dan kesesuainnya dengan masalah penelitian maka dilakukan telaah; (1) keaslian dokumen, (2) kebenaran isi dokumen, dan (3) relevansi isi dokumen dengan permasalahan yang dikaji dalam penelitian.

Analisis data dibagi ke dalam dua tahap; (1) analysis in the field, dan (2) analysis after data collection (Bogdan \& Biklen, 1982: 148). Hasil yang diperoleh pada tahap pertama berupa catatan lapangan (fieldnote) atau fieldwork (Lincoln \& Guba, 1985: 202). Hasil analisis pada tahap ini berupa kesimpulan sementara yang diperoleh dari hasil observasi dan kajian dokumen dengan menggunakan model analisis induktif. Data (kesimpulan) yang diperoleh pada analisis tahap pertama selanjutnya dikembangkan pada analisis tahap kedua, yaitu analysis after data collection. Pada tahap ini, semua data dianalisis secara induktif dengan menggunakan analisis kualitatif deskriptif, yaitu dengan menguraikan berbagai fenomena pengelolaan dan aktivitas sekolah Islam terpadu secara verbal.

\section{PEMBAHASAN}

Sejak era reformasi tahun 1998, Pemerintah Indonesia telah melakukan reformasi pendidikan. Reformasi pendidikan diawali dengan melakukan amandemen Undang-undang Dasar (UUD) 1945, terutama pasal 31 yang mengamanatkan bahwa (1) setiap warga negara berhak mendapatkan pendidikan, (2) pemerintah mengusahakan dan menyelenggarakan sistem pendidikan nasional, (3) setiap warga Negara wajib mengikuti pendidikan dasar dan pemerintah wajib membiayainya, (4) pemerintah mengusahakan dan menyelenggarakan sistem pendidikan nasional untuk meningkatkan iman, takwa, dan akhlak mulia, dan (5) Negara memprioritaskan anggaran pendidikan sekurangkurangnya 20\% dari APBN dan APBD (UUD 1945 pasal 31 ayat $1-5)$.

Pasal 31 UUD 1945 yang merupakan hasil amandemen MPR tahun 2002 itu memberikan amanat kepada pemerintah sebagai pemegang kebijakan di negara ini. Untuk melaksanakan amanat tersebut disusun UU RI No. 20 tahun 2003 tentang Sistem Pendidikan Nasional dan Peraturan Pemerintah No. 19 tahun 2005 tentang Standar Nasional Pendidikan (SNP) (Sutrisno, 2011: 159). Sebagaimana tertuang dalam pasal 31 dari UUD 1945 tersebut dinyatakan bahwa tujuan pendidikan nasional adalah untuk meningkatkan iman, takwa, dan akhlak mulia. Dengan demikian, semua praktek pendidikan di semua lembaga pendidikan di Indonesia, baik pesantren, madrasah, maupun sekolah seharusnya mengacu kepada rumusan tujuan pendidikan yang terdapat dalam UUD 1945 tersebut.

Ada tiga model lembaga pendidikan yang berkembang di Indonesia yaitu sekolah (umum), madrasah (agama), dan pesantren. Sekolah umum dan madrasah merupakan lembaga pendidikan yang secara formal berada di bawah naungan sistem pendidikan nasional. Sekolah umum berada di bawah naungan Kementerian Pendidikan dan Kebudayaan. Madrasah berada di bawah naungan Kementerian Agama. Sedangkan pesantren 
merupakan lembaga pendidikan independen yang tidak berada di bawah naungan kedua kementerian tersebut. Jumlah pesantren telah mencapai $47.000 \mathrm{di}$ seluruh wilayah Indonesia. Perkembangan terakhir, sebagian pesantren diberi pengakuan setara oleh pemerintah dengan dua lembaga pendidikan tersebut sehingga alumni pesantren memiliki ijazah yang dapat digunakan untuk melanjutkan ke jenjang lebih tinggi baik di sekolah umum maupun madrasah.

Tiga model lembaga pendidikan di atas, menurut para pendiri Sekolah Islam Terpadu, telah gagal mewujudkan cita-cita pendidikan nasional. Ketiga lembaga pendidikan itu tidak mampu mencetak generasi yang beriman dan bertakwa kepada Tuhan Yang Maha Esa, berakhlak mulia, sehat, berilmu, cakap, kreatif, mandiri, dan menjadi warga negara yang demokratis serta bertanggung jawab. Sekolah umum hanya melahirkan alumni yang menguasai sains dan teknologi namun jauh dari nilai-nilai tauhid. Pesantren hanya dapat mencetak alumni-alumni yang hanya sebatas menguasai ilmuilmu agama yang dianggap tidak cukup untuk eksis dalam kehidupan modern. Sedangkan madrasah yang awalnya ingin menjembatani keduanya, hingga kini masih belum mampu memberi keyakinan kepada masyarakat.

Di tengah-tengah kegelisahan itu, sebagian para aktivis Muslim Indonesia bekerja sama untuk mendirikan model lembaga pendidikan alternatif yang mampu mengintegrasikan antara penguasaan sains dan teknologi dan basic pendidikan agama yang kuat. Para aktor gerakan Sekolah Islam Terpadu mengungkapkan bahwa saat ini kondisi pendidikan nasional di Indonesia sedang mengalami keterpurukan. Padahal pada masa-masa sebelumnya, baik pada masa Nabi beserta Sahabat dan zaman kekholifahan Bani Umayyah maupun Bani Abbasiyah, pendidikan Islam mengalami puncak kejayaan. Salah seorang pengurus Jaringan Sekolah Islam Terpadu mengungkapkan:

Jika mengingat sejarah munculnya Sekolah Islam Terpadu pada tahun 1990an, sebenarnya sekolah ini muncul sebagai rasa kekecewaan para aktivis terhadap kondisi pendidikan di Indonesia saat itu. Para aktivis menganggap bahwa pendidikan di Indonesia belum cukup mewakili praktek pendidikan yang dicontohkan oleh Nabi Muhammad saw. Praktek pendidikan di Indonesia cenderung memisahkan antara ilmu agama dan ilmu umum sehingga membuat anak didik mengalami split personality. Oleh karena itu
Sekolah Islam Terpadu menawarkan satu model pendidikan yang terintegrasi antara pendidikan agama dan pendidikan umum (Wawancara dengan MZ, pengurus JSIT Wilayah Yogyakarta).

Hasil wawancara di atas menunjukkan bahwa para pendiri Sekolah Islam Terpadu mendambakan sebuah praktek pendidikan sebagaimana yang telah dicontohkan oleh Nabi Muhammad beserta para Sahabat dulu. Mereka menilai bahwa praktek pendidikanyang dilaksanakanoleh Nabi Muhammad dan para Sahabat dulu telah menghasilkan manusiamanusia hebat yang memiliki kedalaman akhlak dan ilmu sekaligus. Kondisi seperti itu terus berlanjut ke masa-masa tabi'in. Salah seorang pendiri Sekolah Islam Terpadu mengungkapkan:

Pada saat itu, dunia Islam mampu melahirkan tokoh-tokoh ilmuwan kaliber dunia dan bersama dengan perkembangan ilmu tersebut berkembang dan maju peradaban Islam. Kondisi tersebut sangat berbeda dengan kondisi saat ini. Saat ini, kondisi pendidikan Islam seperti tidak berdaya dalam menghadapi kemajuan sains dan teknologi yang datang dari Barat. Hal ini didukung sebagian umat Islam yang masih menganggap sebelah mata terhadap ilmuilmu umum karena mempelajarinya masih dianggap sebatas fardhu kifayah. Dalam kondisi ini, dikotomi masih sangat kuat dan pelaksanaan pendidikan Islam hanya mampu menyesuaikan diri dengan pendidikan Barat yang sekuler (Masruri, 2011:7).

Sebenarnya telah banyak para cendekiawan Muslim yang menawarkan berbagai cara untuk mengatasi permasalahan-permasalahan tersebut. Fazlur Rahman, seorang cendekiawan Muslim asal Pakistan, menawarkan salah satu pendekatannya dengan cara menerima pendidikan sekuler modern sebagaimana yang berkembang di Barat dan mencoba untuk mengislamkannya, yakni mengisinya dengan konsep-konsep kunci tertentu dari Islam. Pendekatan yang ditawarkan ini, menurutnya memiliki dua tujuan, yaitu: pertama, upaya membentuk watak pelajar dan mahasiswa dengan nilai Islam dalam kehidupan individu dan masyarakat; kedua, para ahli yang berpendidikan modern untuk menamai bidang kajian masingmasing dengan nilai Islam pada perangkatperangkat yang lebih tinggi menggunakan perspektif Islam untuk mengubah kandungan maupun orientasi kajian-kajian mereka (Rahman, 
1985: 160). Senada dengan Rahman, al-Faruqy menyatakan bahwa sistem pendidikan Islam harus dipadukan dengan sistem sekuler. Perpaduan kedua sistem pendidikan tersebut diharapkan akan lebih banyak dapat dilakukan daripada sekedar memakai cara-cara sistem Islam dan cara-cara otonomi sistem sekuler (Al-Faruqy, 1984: 25). Dengan demikian, ilmu-ilmu agama Islam akan selalu bersinggungan dengan realitas kehidupan sehari-hari dan ilmuilmu umum modern dapat dibawa dan dimasukkan ke dalam kerangka sistem Islam (Nakosteen, 1996: 212-218) (Muqowim, 2012: 113-282).

Meskipun lahir sebagai kritik terhadap kelemahan sistem pendidikan nasional, dalam perkembangannya, Sekolah Islam Terpadu ternyata justru menjadi bagian dari sistem pendidikan nasional. Setidaknya ada empat indikator yang dapat digunakan untuk melihat bahwa Sekolah Islam Terpadu merupakan bagian (subsistem) dari sistem pendidikan nasional di Indonesia, yaitu; 1) penggunaan nama sekolah; 2) adopsi kurikulum nasional; 3) penyesuaian sistem ujian, dan 4) sertifikasi guru oleh guru-guru sekolah Islam terpadu. Keempat indikator ini dibahas secara memadai dalam paragraf-paragraf berikut ini.

\section{Penggunaan Nama "Sekolah"}

Penggunaan nama "sekolah" pada Sekolah Islam Terpadu menunjukkan bahwa lembaga pendidikan ini secara kelembagaan lebih dekat kepada ciri sekolah umum, bukan madrasah maupun pesantren. Penggunaan istilah "sekolah" telah diakui oleh para pendiri Sekolah Islam Terpadu bahwa mau tidak mau mereka secara administratif berada di bawah naungan Kementerian Pendidikan dan Kebudayaan. Di sisi lain, penggunaan nama "sekolah" didasarkan atas pertimbangan pragmatis bahwa selama ini sekolah lebih diminati oleh para peserta didik dari berbagai kalangan di Indonesia daripada madrasah maupun pesantren. Hal ini terungkap dari wawancara penulis dengan salah seorang kepala Sekolah Islam Terpadu:

Penggunaan nama sekolah sebenarnya lebih kepada pertimbangan pragmatis saja karena selama ini masyarakat lebih senang menyekolahkan anaknya ke sekolah daripada ke madrasah. Namun agar tidak sama dengan sekolah pada umumnya maka kami menmbah dengan kata terpadu. Terpadu sendiri merupakan simbol kami dalam upaya untuk mengintegrasikan antara ilmu umum dan agama (Wawancara, SW-salah seorang kepala SDIT di Yogyakarta).
Meskipun di dasari oleh pertimbangan pragmatis, penggunaan nama "sekolah" terbukti telah membangun citra Sekolah Islam Terpadu sebagai lembaga pendidikan yang responsif terhadap perkembangan zaman modern di kalangan masyarakat yang tidak memiliki basic keagamaan yang kuat. Sebagaimana jamak diketahui, sekolah merupakan lembaga pendidikan modern warisan penjajah Belanda. Dibandingkan dengan lembaga pendidikan yang telah berkembang sebelumnya, sekolah memiliki keunggulan dari segi pengembangan sains dan teknologi.

Sedangkan kata "terpadu" merupakan konsep yang digunakan untuk membangun citra sekolah islam terpadu bahwa di samping pengembangan sains dan teknologi, mereka juga mengembangkan pendidikan agama yang excellent. Kata "terpadu" sendiri merupakan simbol adanya kesatupaduan antara pengembangan sains dan teknologi dengan ilmu-ilmu keislaman. Salah seorang guru mengungkapkan:

Terpadu adalah simbol utama sekolah kami. Terpadu di sini berarti adanya pemaduan antara ilmu umum dan agama. Di sekolah kami sebenarnya tidak ada penamaan antara mata pelajaran umum dan mata pelajaran agama. Semua mata pelajaran adalah agama karena tujuan akhirnya agar anak bertauhid (Wawancara, T-Guru Sekolah Islam Terpadu Wilayah Yogyakarta).

Bahkan bukan hanya sebagai ilmu, islam dijadikan sebagai worldview bagi pengembangan karakter peserta didik. Harapannya, peserta didik tidak hanya menguasai ilmu-ilmu keislaman, melainkan ajaran islam menjadi pondasi dalam kehidupan sehari-hari.

\section{Adopsi Kurikulum Nasional}

Sekolah Islam Terpadu secara total mengadopsi kurikulum dari Kementerian Pendidikan dan Kebudayaan. Semua mata pelajaran yang ada dalam kurikulum Kementerian Pendidikan dan Kebudayaan sepenuhnya "diterima" dan diajarkan dalam kurikulum Sekolah Islam Terpadu. Lima rumpun mata pelajaran yang ada dalam Undangundang Sistem Pendidikan Nasional yang terdiri dari rumpun mata pelajaran Agama dan Akhlak Mulia, Kewarganegaraan dan Kepribadian, Ilmu Pengetahuan dan Teknologi, Estetika, serta Jasmani, Olah Raga, dan Kesehatan merupakan bagian integral dari struktur kurikulum Sekolah Islam Terpadu. Bahkan diakui oleh para pendiri Sekolah Islam Terpadu, lima rumpun mata pelajaran tersebut 
merupakan bagian dari ajaran Islam. Kelima rumpun mata pelajaran tersebut tidak bertentangan dengan ajaran Islam. Selain itu, mempelajari sains dan teknologi merupakan bagian pengabdian seorang hamba kepada Allah swt. Sekolah Islam Terpadu hanya menambah beberapa mata pelajaran dalam struktur kurikulumnya, yang dinamakan dengan program ke-Islam Terpadu-an (ke-IT-an) (Dokumentasi struktur kurikulum SDIT, Bab IV, 278-279). Oleh karena itu, diintegrasikannya antara kurikulum pendidikan agama dan umum ditambah dengan program ke-IT-annya merupakan upaya untuk melakukan islamisasi kurikulum pendidikan.

Kurikulum Sekolah Islam Terpadu juga membawa dampak islamisasi kegiatan pembelajaran di kelas. Kurikulum Sekolah Islam Terpadu melakukan islamisasi proses pembelajaran dengan tujuan untuk membentuk kesadaran dan pola berpikir secara integral dalam perspektif Islam. Wujud islamisasi kegiatan pembelajaran di kelas adalah adanya pembelajaran yang terintegrasi antara berbagai mata pelajaran. Semua guru dituntut untuk menyajikan semua materi pembelajaran sebagai bagian dari proses pendidikan melalui pendekatan integral. Bahkan indikator-indikator yang digunakan untuk mengukur tercapainya sebuah kompetensi tidak hanya dilihat dari penguasaan terhadap indikator-indikator dari mata pelajaran saja, namun juga dilihat dari komitmen keislamannya.

Islamisasi kurikulum dipengaruhi oleh pandangan bahwa Islam tidak mengenal adanya pemisahan antara ilmu umum dan ilmu agama. Tindakan membedakan serta mengkotakkotakkan pendidikan umum di satu pihak dan pendidikan agama di pihak lain merupakan penyebab utama dari kerancuan dan kesenjangan pendidikan di Indonesia dengan segala akibat yang ditimbulkannya. Dampak dari sistem pendidikan yang dualistis adalah adanya penyempitan terhadap makna agama hanya sejauh yang berkaitan dengan aspek teologi Islam seperti yang diajarkan baik di pesantren, madrasah, maupun pendidikan agama Islam di sekolah umum (Saridjo, 1996:21).

Tujuan pendidikan nasional, bagi mereka, tidak mungkin tercapai melainkan dengan kembali kepada paradigma pendidikan Islam, yakni pendidikan yang telah dicontohkan oleh Nabi Muhammad saw. dan para salaf al-sālih. Pendidikan harus dijauhkan dari sistem sekuler sebagaimana yang berjalan saat ini. Pendidikan harus dikembalikan kepada ruh dan spirit ajaran Islam (Masruri, 2011).

Hal ini juga dipengaruhi oleh paradigma bahwa Islam adalah agama yang käffah dan merupakan sistem kehidupan yang menyeluruh yang di dalamnya memuat sistem ekonomi, politik, sosial, dan pendidikan. Agama harus wujud dalam semua aspek kehidupan sehingga tidak dibenarkan adanya penyempitan terhadap makna agama bahwa agama hanya dimaknai sebagai aspek teologis normatif sebagaimana yang diajarkan oleh pesantren, madrasah, ataupun Pendidikan Agama Islam di sekolah umum.

Meskipun madrasah juga menggabungkan kurikulum umum dengan kurikulum agama, dengan tegas dinyatakan bahwa porsi kurikulum madrasah adalah $70 \%$ mata pelajaran umum dan $30 \%$ mata pelajaran agama. Hal ini juga sesuai dengan filosofi berdirinya madrasah di negeri ini yaitu untuk menjembatani kesenjangan yang demikian lebar antara pesantren sebagai pendidikan tradisional dan sekolah umum sebagai lembaga pendidikan modern. Diakui bahwa kurikulum madrasah merupakan upaya integrasi antara mata pelajaran agama dan dengan mata pelajaran umum. Namun, integrasi di madrasah, menurut para pendiri Sekolah Islam Terpadu, hanya sebatas pada kurikulum formal saja dan tidak tidak pernah menyentuh ranah epistemologi keilmuan.

Tabel 1. Mata Pelajaran Sekolah Islam Terpadu

\begin{tabular}{ccccc}
\hline No & MATA PELAJARAN & KLS 1-2 & KLS 3 & KLS 4-6 \\
\hline 1 & Pendidikan Agama/Praktik Ibadah & & 4 & 4 \\
2 & Kewarganegaraan & & 2 & 2 \\
3 & Bahasa Indonesia dan Sastra & & 5 & 5 \\
4 & Matematika & 6 & 6 \\
5 & Sains & 3 & 4 \\
6 & Pengetahuan Sosial & Tematik 28 jam & 3 & 2 \\
7 & Bahasa Inggris & & 2 & 2 \\
8 & Pendidikan Jasmani/Kesehatan & & 2 & 2 \\
9 & Keterampilan dan kesenian & & 2 & 2 \\
10 & Kepanduan & 2 & 2 \\
11 & Bahasa Arab & 10 & 2 & 6 \\
12 & Tilawah/Tahsin Al-Qur'an & 38 & 6 & 47 \\
\hline
\end{tabular}

Sumber: Struktur Kurikulum JSIT Wilayah Yogyakarta. 
Kurikulum Sekolah Islam Terpadu merupakan integrasi yang dilakukan pada level epistemologis sehingga betul-betul dapat menghilangkan sekat dikotomi antara kedua rumpun keilmuan. Sekolah Islam Terpadu bukan sekedar apa yang disebut Steenbrink sebagai "penghargaan umat Islam terhadap pengetahuan umum" (Stenbrink, 1986: 222), bukan pula "sekolah umum yang diperbanyak pelajaran agamanya" sebagaimana anggapan mayarakat Islam terhadap pendidikan madrasah. Sekolah Islam Terpadu merupakan perwajahan baru dari model pendidikan yang kompleks dan melebihi batas-batas integrasi formal.

Islamisasi kurikulum yang dilakukan sekolah Islam terpadu juga memberikan corak baru dalam perkembangan islamisasi masyarakat Indonesia yang oleh sebagian pakar disebut dengan santrinisasi. Proses santrinisasi melalui Sekolah Islam Terpadu berlangsung melalui berbagai model. Para siswa di Sekolah-Sekolah Islam Terpadu pada umumnya telah mengalami proses reislamisasi (Nakamura, 1976) (Benda, 1958:9). Dalam arti, peserta didik mendapat didikan ajaran dan praktikpraktik Islam secara intens dan terarah. Kegiatankegiatan ekstrakurikuler yang dilakukan dalam kerangka penanaman nilai-nilai keagamaan, secara langsung atau tidak langsung telah mempengaruhi kedalaman wawasan keislaman anak didik. Selain itu, para siswa di Sekolah Islam Terpadu membawa pulang ke rumah masing-masing dan menyampaikan pengetahuan keislaman itu kepada anggota keluarganya. Dalam banyak kasus, orang tua kadang merasa malu bila mendapat pelajaran dari anaknya. Akibatnya, orang mencari tahu tentang Islam baik melalui buku-buku, CD, kaset atau mengundang guru privat ke rumah (Azra, 2012).

Dorongan yang datang dari anak (atau anggota keluarga) untuk mempelajari Islam seringkali lebih menyentuh dari pada dorongan dari luar, sehingga dalam keluarga terjadi proses saling mengingatkan antara anak dan orang tua untuk menjalani kehidupan yang islami. Hal demikian juga menimbulkan dampak berbeda dari keberadaan Sekolah Islam Terpadu. Kehadiran Sekolah Islam Terpadu ternyata tidak hanya melakukan islamisasi di lembaga pendidikan formal di kelas, namun juga berdampak langsung terhadap perkembangan keislaman di masyarakat umum. Hal ini merupakan konsekuensi logis dari pengelolaan Sekolah Islam Terpadu yang memang melibatkan pihak-pihak di luar sekolah yakni masyarakat dan orang tua. Sekolah Islam Terpadu melakukan integrasi keikutsertaan antar berbagai pihak untuk bersama-sama melakukan perubahan dalam bidang pendidikan.

Bahasa Arab dan Bahasa Inggris juga menjadi komponen penting dalam pengembangan kurikulum di sekolah islam terpadu. Dua bahasa ini dikembangkan scara seimbang untuk membekali anak agar dapat hidup di era global. Khusus Bahasa Arab dikembangan dalam rangka untuk membekali anak didik agar dapat memahami Alquran dan juga teks-teks keislaman yang lain. Bahasa inggris dikembangkan dengan alasan bahwa peradaba dunia saat ini dikuasai oleh bangsa Barat yang notabene menggunakan bahasa inggris. Salah seorang guru SDIT menuturkan:

Kita semua tahu bahwa al-quran sebagai kitab suci orang islam diturunkan dalam bahasa arab. Oleh karena itu, bahasa arab menjadi bahasa wajib di sekolah islam terpadu. Meskipun di SDIT baru sebatas pengenalan, tapi ini penting sebagai bentuk pembiasaan bagi anak sekaligus menanamkan rasa cinta bahasa arab kepada anak didik (Wawancara, K-Guru SDIT di Wilayah Yogyakarta).

Penguasaan bahasa arab diharapkan para siswa memiliki bekal yang cukup untuk mempelajari kitab suci al-quran. Meskipun pembelajaran bahasa arab di SDIT baru pengenalan, hal ini dianggap penting agar siswa dapat mengenal, membiasakan, dan memiliki rasa cinta terhadap bahasa yang dipakai al-quran diturunkan.

Berbeda dengan bahasa arab, bahasa inggris juga menjadi bagian dalam kurikulum Sekolah Islam Terpadu dengan alasan agar anak didik memiliki wawasan yang luas dan mampu mengikuti perkembangan informasi. Salah seorang guru SDIT mengungkapkan:

Bahasa inggris juga penting bagi anak didik. Sekarang kan peradaban dikuasasi oleh orang Barat yang bahasa pengantarnya pakai bahasa inggris. Jadi mau gak mau anak juga dikenalkan dengan bahasa inggris. Kalau tidak mereka akan kuper dan tidak percaya diri. Selain itu dengan bahasa inggris mereka juga mudah memperoleh informasi (Wawancara Aca-Guru SDIT Wilayah Yogyakarta).

Namun demikian, fakta menunjukkan bahwa realitas di lapangan belum sesuai konsep yang dicita-citakan. Integrasi antara ilmu agama dan ilmu umum di sekolah Islam terpadu baru sebatas 
menempelkan ayat-ayat al-Quran yang tampak relevan dengan tema keilmuan tertentu atau sebatas mengganti konteks cerita dengan cerita-cerita yang berbau Islam (Hasil observasi pembelajaran di kelas, November 2014). Meminjam konsep yang dipopulerkan oleh Bastaman (1997), integrasi di Sekolah Islam Terpadu baru masuk pada tahap similarisasi dan paralelisasi.

\section{Penyesuian Sistem Evaluasi Sekolah}

Sekolah Islam Terpadu melaksanakan sistem penilaian sebagaimana yang dilaksanakan oleh lembaga pendidikan yang berada di bawah naungan Kementerian Pendidikan dan Kebudayaan maupun Kementerian Agama. Salah seorang guru mengungkapkan:

Kita memang harus menyesuaikan dengan sistem ujian sekolah karena kita memang belum memiliki setiap jenjang sekolah sehingga sebagian besar siswa setelah lulus melanjutkan di sekolah umum sehingga mereka butuh ijazah yang dapat diterima oleh sekolah tersebut (Wawancara, MZ, Guru SDIT Wilayah Yogyakarta).

Sistem penilaian terdiri dari ulangan harian, ulangan tengah semester, ulangan akhir semester, dan ulangan kenaikan kelas; sedangkan ujian meliputi ujian nasional dan ujian sekolah. Sistem penilaian tersebut dilaksanakan sebagai konsekuensi logis dari adopsi kurikulum yang dilakukan oleh Sekolah Islam Terpadu. Selain itu, fakta bahwa tidak semua alumni Sekolah Islam Terpadu melanjutkan di sekolah yang sama pada jenjang berikutnya mengharuskan sekolah ini melaksanakan sistem penilaian yang diakui oleh lembaga-lembaga pendidikan lain.

Namun demikian, Sekolah Islam Terpadu sangat menekankan penilaian aspek afektif dan psikomotorik, selain penilaian kognitf melalui ulangan harian, ujian tengah semester, maupun ujian akhir sekolah. Penilaian sikap dilakukan melalui pengamatan guru setiap hari. Kedekatan hubungan antara guru dan siswa di sekolah sangat memudahkan bagi guru untuk memberikan penilaian secara autentik dan objektif. Penilaian ketrampilan diutamakan dengan praktek.

Untuk menopang penilaian siswa secara komprehensif, sekolah juga menerapkan adanya buku penghubung. Buku penghubung ini dipakai sebagai sarana komunika antara guru dengan orang tua siswa agar perkembangan siswa di sekolah juga terpantau oleh guru.

\section{Program Sertifikasi Bagi Guru Sekolah Islam Terpadu}

Keberadaan dan profesi guru di Sekolah Islam Terpadu juga menjadikan lembaga pendidikan ini semakin kuat ketergantungannya dengan Sistem Pendidikan Nasional. Meskipun guru di Sekolah Islam Terpadu memiliki kriteria yang berbeda dibandingkan dengan sekolah-sekolah lain, misalnya; diseleksi oleh JSIT, diwajibkan memiliki hafalan dari beberapa juz al-Quran, memakai kerudung besar bagi guru perempuan. Keberadaan guru di sekolah ini tidak dapat lepas sepenuhnya dari kebijakan pendidikan nasional. Sebagaimana para guru di sekolah-sekolah lain, para guru di Sekolah Islam Terpadu juga mengikuti program sertifikasi guru yang dilakukan oleh pemerintah. Hal ini merupakan konsekuensi dari Sekolah Islam Terpadu sebagai sekolah swasta yang tidak sepenuhnya mampu memberi gaji guru dari kantong pribadi sekolah. Berdasarkan wawancara peneliti dengan seorang guru diperoleh data sebagai berikut:

\begin{abstract}
Alhamdulillah saya telah diajukan sertifikasi guru. Teman-teman yang senior sudah lebih duluan. Itu hak saya sebagai seorang guru di Indonesia. Karena kami akui sekolah sendiri memang belum bisa memberikan gaji yang mencukupi karena sumber dana sekolah swasta kebanyakan hanya dari siswa (Wawancara, Ts, guru SDIT Wilayah Yogyakarta).
\end{abstract}

Program sertifikasi guru yang diatur dalam undang-undang No. 14 tahun 2005 tentang guru dan dosen merupakan salah satu upaya yang dilakukan oleh pemerintah Indonesia untuk memperbaiki kualitas tenaga pendidik. Salah satu poin penting program ini adalah program peningkatan kualifikasi dan kompetensi guru. Namun di samping itu, guru-guru yang telah dinyatakan lulus sertifikasi mendapatkan tunjangan kesejahteraan sebesar satu kali gaji per bulan. Karena itu, program sertifikasi guru menjadi salah satu daya tarik tersendiri bagi masyarakat luas terhadap profesi guru. Tidak salah jika sekarang para alumni sekolah menengah di Indonesia berbondong-bondong mendaftar di fakultas keguruan. Demikian halnya dengan sekolah Islam terpadu, meskipun mereka pada awalnya banyak mengkritik sistem pendidikan nasional, banyak guru sekolah Islam terpadu juga ikut program sertifikasi. 


\section{PENUTUP}

Berdasarkan analisis data yang ditemukan di lapangan, penelitian ini menyimpulkan bahwa Sekolah Islam Terpadu merupakan bagian integral dari sistem pendidikan nasional di Indonesia. Hal ini tampak pada penggunamaan nama sekolah, kesediaan sekolah Islam terpadu untuk menerima sepenuhnya kurikulum yang berasal dari Kementerian Pendidikan dan Kebudayaan, pelaksanaan ujian yang menyesuaikan dengan ujian yang diselenggarakan oleh pemerintah, dan program sertifikasi oleh guru-guru di sekolah Islam terpadu.

Melihat empat indikator di atas, jelas bahwa meskipun munculnya sekolah Islam terpadu merupakan respon atas ketidakpuasan terhadap praktek pendidikan di Indonesia, hingga saat ini, Sekolah Islam Terpadu tetap menjadi bagian integral dari sistem pendidikan nasional. Oleh karena itu, keberadaan Sekolah Islam Terpadu lebih tepat jika dikatakan sebagai upaya untuk melakukan islamisasi terhadap lembaga pendidikan formal di Indonesia. Islamisasi dilakukan terhadap semua komponen pendidikan, baik tujuan pendidikan, kurikulum, strategi, sumber belajar, hingga guru yang dianggap sebagai ujung tombak dalam pendidikan.

Pekerjaan rumah bagi para aktor gerakan Sekolah Islam Terpadu adalah bagaimana mereka mampu membuat diferensiasi dengan ketiga lembaga pendidikan yang telah ada sebelumnya, baik pesantren, madrasah, maupun sekolah umum. Jika dalam perkembangan sekolah ke depan tidak mampu memberi jawaban atas ketidakpuasan sebagian kalangan terhadap sistem pendidikan di Indonesia, bukankah berarti bahwa Sekolah Islam Terpadu telah gagal mewujudkan cita-cita awal. Pesantren, madrasah, dan sekolah umum yang menjadi model lembaga pendidikan di Indonesia dianggap belum mampu mewujudkan tujuan pendidikan yang diidealkan oleh umat Islam. Bahkan untuk mewujudkan tujuan pendidikan nasional pun masih jauh dari harapan. Sebagaimana dinyatakan dalam Undang-undang No. 20 tahun 2003 tentang Sistem Pendidikan Nasional, tujuan pendidikan nasional adalah membentuk manusia yang beriman dan bertakwa kepada Tuhan Yang Maha Esa, berakhlak mulia, sehat, berilmu, cakap, kreatif, mandiri, dan menjadi warga negara yang demokratis serta bertanggung jawab. Namun demikian, Sekolah Islam Terpadu ternyata tidak mampu menjawab kritikannya sendiri. Alih-alih untuk melakukan perbaikan terhadap sistem pendidikan nasional, Sekolah Islam Terpadu justru masuk dalam satu habitat yang sama dengan lembaga pendidikan yang menjadi sasaran kritiknya.

\section{UCAPAN TERIMA KASIH}

Penulis ucapkan terima kasih kepada seluruh informan pada Sekolah Islam Terpadu di wilayah Yogyakarta dari tingkat TK hingga SMA yang telah membatu peneliti ketika penelitian ini dilakukan dan kepada semua pihak atas bantuan sehingga penelitian ini terlaksana. Dan kepada redaksi jurnal Al-Qalam atas terbitnya tulisan ini terima kasih penulis ucapkan.

\section{DAFTAR PUSTAKA}

Al-Faruqy, Ismail Raji. 1984. Islamisasi Pengetahuan. terj. Anas Mahyudin. Bandung: PustakaPerpustakaan Salman Institute Teknologi.

Azra, Azyumardi. 1998. Pendidikan Islam, Tradisi dan Modernisasi Menuju Millennium Baru, Jakarta: Logos Wacana Ilmu.

Bastaman, Hanna Djumhana. 1997. Integrasi Psikologi dengan Islam. Yogyakarta: Pustaka Pelajar.

Benda, Harry J. 1958. The Cresent and The Rising Sun: Indonesian Islam Under The Japanese Occupation 1942-1945. The Hague and Bandung: Van Hoeve.

Bogdan R.C. \& Biklen, S.K., 1982. Qualitative Research For Education: An Introduction To Theory and Methods. Boston: Allyn and Bacon, Inc.

Buku Struktur Kurikulum Sekolah Dasar Islam Terpadu, Bab IV.

Hasan, Noorhaidi. 2011. "Islamizing Formal Education: Integrated Islamic School and New Trend in Formal Education Institution in Indonesia". Artikel. S. Rajartanam School of International Studies Singapore.

Hisyam, Usamah. 2011. Sepanjang Jalan Dakwah Tifatul Sembiring. Jakarta: PT Dharmapena Citra Media.

Lincoln \& E. G. Guba. 1985. Naturalistic Inquiry. California: Sage Publications Inc.

Masruri, Eri. "Membangun Paradigma Baru Pendidikan Islam Terpadu" sebuah alternatif, Makalah, disampaikan dalam diskusi pendirian Jaringan Sekolah Islam Terpadu (JSIT) Yogyakarta.

Moleong, Lexy J. 1989. Metodologi Penelitian Kualitatif, Cet. XXII, Bandung: Remaja Rosdakarya. 
Muhadjir, Noeng. 2002. Metodologi Penelitian Kualitatif (ed. IV). Yogyakarta: Andi Offset.

Muqowim.2012. Genealogi IntelektualSaintis Muslim Sebuah Kajian tentang Pola Pengembangan Sains dalam Islam pada Periode 'Abbasiyyah. Jakarta: Kementerian Agama RI.

Nakamura, Mitsuo. 1976. "The Cresent Arises Over The Banyan Tree: A Study of The Muhammadiyah Movement in A Central Javanese Town". Disertasi. Cornell University: 1993. The Emergence of Islamizing Middle Class and the Dialectics of Political Islam in the New Order of Indonesia: Preludes to Informations of the ICMI. A paper presented at Honolulu's seminar on "Islam and the Sosial Construction of Identities: Comparative Perspective on Southeast Asian Muslim.

Nakosteen, Mehdi. 1996. Kontribusi Islam atas Dunia Intelektual Barat Deskripsi Analisis Abad Keemasan Islam. terj. Joko S. Kahhar dan Supriyanto Abdullah. Surabaya: Risalah Gusti.

Nasution, S. 1998. Metode Penelitian Naturalistik Kualitatif. Bandung: Tarsito.

Rahman, Fazlur. 1985. Islam dan Modernitas tentang Transformasi Intelektual. terj. Ahsin Mohammad. Bandung: Pustaka.

Sanaky, Hujair A.H. 2003. Paradigma Pendidikan Islam: Membangun Masyarakat Madani
Indonesia, Yogyakarta: Safiria Insania Press.

Saridjo, Marwan. 1996. Bunga Rampai Pendidikan Agama Islam. Jakarta: CV. Amisso.

Standar Penilaian diatur dalam Peraturan Menteri Pendidikan Nasional Republik Indonesia Nomor 20 Tahun 2007 Tentang Standar Penilaian Pendidikan.

Steenbrink, Karel A. 1986. Pesantren, Madrasah, Sekolah. Jakarta: LP3ES The Columbia Encyclopedia (1963) NY \& London: Colombia University Press.

Sugiyono. 2006. Metode Penelitian Pendidikan: Pendekatan Kualitatif, Kuantitatif, dan R\&D. Bandung: Alfabeta.

Sutrisno. 2011. Pembaharuan dan Pengembangan Pendidikan Islam. Yogyakarta: Fadhilatama.

Suyatno. 2013a. "Sekolah Islam Terpadu: Filsafat, Ideologi, dan Tren Baru Pendidikan Islam Di Indonesia", Jurnal Pendidikan Islam, Volume II, Nomor 2.

.2013b. "Sekolah Islam Terpadu (Genealogi, Ideologi, dan Sistem Pendidikan)”. Disertasi. Program Pascasarjana UIN Sunan Kalijaga Yogyakarta.

Undang-Undang Dasar Negara Republik Indonesia tahun 1945 Pasal 31, ayat 1-5.

Yin, Robert K. 1996. Case Study Research, Design And Methods. Terj. M. Jaudzi Mudzakir. Jakarta: PT Raja Grafindo Persada. 